\title{
The influence of social and living environment on development of oral hygiene habits in people over the age of 65
}

\begin{abstract}
Introduction. Oral health largely depends on proper hygiene, which in elderly people is not different from generally accepted standards, however, must be adjusted to specific conditions in oral cavities of the elderly.

Aim. The aim of the study was the assessment of oral hygiene habits in people over the age of 65 residing in Lublin Nursing Homes and in family homes basing on questionnaire survey.

Material and methods. The study was conducted among 240 people over the age of 65: 117 residents of the four Lublin Nursing Homes (group I) and 123 seniors living in their own homes in Lublin (group II). Assessment of the oral hygiene habits was conducted basing on the questionnaire survey concerning the frequency of tooth brushing, type of toothpaste, the use of additional oral aids as well as the frequency of toothbrush replacement.

Results. Questionnaire survey revealed that seniors residing in Nursing Homes who had their own teeth most frequently brushed them once daily e.g. $37.25 \%$, whereas the surveyed who lived in their family homes twice daily $-47.67 \%$. In both groups the people who brushed their teeth used fluoride toothpastes. Additional oral hygiene aids were used by $31.71 \%$ of the surveyed living with their families. Both, the residents of Nursing Homes and those who lived with their families most frequently reported replacing their toothbrushes at least every 3 months.

Conclusions. Nursing Homes residents essentially more frequently revealed considerable neglect and irregularities in oral hygiene in comparison to seniors living with their families. Population of elderly people, especially residents of nursing homes, should be provided with complex dental care.
\end{abstract}

Keywords: geriatric dentistry, the aged, oral hygiene, nursing homes.

DOI: $10.2478 / \mathrm{pjph}-2014-0014$

\section{INTRODUCTION}

In the last several dozen years, the increase in the life span has been observed which results in the growing number of the elderly population [1-4]. These demographic changes mainly concern highly developed countries, however, currently we can observe a tendency of aging society in Poland as well. The growing number of seniors resulted in their more and more frequent dental appointments and, thus, the necessity of providing proper dental care [5]. Due to the current tendency of the increase of the preserved natural teeth in the elderly, a complex treatment including conservative, periodontal, surgical and prosthetic treatment plays a vital role $[1,3,6]$. It aims at restoration of complete function of stomatognathic system as well as obtaining a satisfactory aesthetic effect.

Oral health largely depends on proper hygiene, which in elderly people is not different from generally accepted standards, however, must be adjusted to specific conditions in oral cavities of the elderly [7]. Frequently dexterity and mobility impairments occur in the elderly, which decrease the activity and agility and considerably hinder life activities including those concerning oral health and prosthetic restorations [8]. Oral hygiene negligence leads to accumulation of dental plaque and prosthetic plaque which may be one of the reasons of the prosthetic stomatopathies as well as other pathologies of the oral cavity [2,9].

\section{AIM}

The aim of the study was assessment of oral hygiene habits in people over the age of 65 residing in Lublin Nursing Homes and in family homes basing on questionnaire survey.

\section{MATERIAL AND METHODS}

The study was conducted among 240 people aged over 65 , including 120 women and 120 men. Patients were divided into two groups. The first one comprised 117 residents of the four Lublin Nursing Homes (48.75\%). The second group included 123 seniors residing in their family homes and reporting to Clinical Dental Centre Medical University in Lublin (51.25\%). The mean age of the Lublin Nursing Homes 
residents was $75.91 \pm 7.50$ whereas the mean age of people residing in their family homes was $73.69 \pm 6.10$.

The majority of surveyed from the Nursing Homes had elementary education e.g. $53.85 \%$, whereas $21.37 \%$ secondary education, $17.95 \%$ had vocational training and only $6.83 \%$ - higher education. In the group of people living with their families the largest percentage had secondary education e.g. $34.96 \%$, whereas $30.89 \%$ - elementary education, $18.70 \%$ - higher and $15.45 \%$ - vocational training.

The assessment of hygiene habits was conducted basing on questionnaire survey concerning the frequency of tooth brushing, type of toothpaste, the use of additional hygiene aids as well as the frequency of toothbrush replacement. All patients revealed good contact with environment, were physically fit and expressed their consent.

Bioethics Committee of the Medical University of Lublin approved of carrying out investigation

TABLE 1. The frequency of tooth brushing in the examined groups depending on place of living.

\begin{tabular}{|c|c|c|c|c|c|}
\hline \multirow[b]{2}{*}{ Group } & Once a day & Twice a day & $\begin{array}{l}\text { After every } \\
\text { meal }\end{array}$ & $\begin{array}{l}\text { Doesn't } \\
\text { brush }\end{array}$ & Total \\
\hline & $\begin{array}{c}\text { number of } \\
\text { people } \\
\%\end{array}$ & $\begin{array}{c}\text { number of } \\
\text { people } \\
\%\end{array}$ & $\begin{array}{c}\text { number of } \\
\text { people } \\
\%\end{array}$ & $\begin{array}{c}\text { number of } \\
\text { people } \\
\%\end{array}$ & $\begin{array}{c}\text { number of } \\
\text { people } \\
\%\end{array}$ \\
\hline \multirow{2}{*}{$\begin{array}{l}\text { Nursing } \\
\text { homes }\end{array}$} & 19 & 10 & 2 & 20 & 51 \\
\hline & $37.25 \%$ & $19.61 \%$ & $3.92 \%$ & $39.22 \%$ & $100.00 \%$ \\
\hline \multirow{2}{*}{$\begin{array}{l}\text { Family } \\
\text { homes }\end{array}$} & 28 & 41 & 13 & 4 & 86 \\
\hline & $32.56 \%$ & $47.67 \%$ & $15.12 \%$ & $4.65 \%$ & $100.00 \%$ \\
\hline \multirow{2}{*}{ Total } & 47 & 51 & 15 & 24 & 137 \\
\hline & $34.30 \%$ & $37.23 \%$ & $10.95 \%$ & $17.52 \%$ & $100.00 \%$ \\
\hline
\end{tabular}

TABLE 2. The type of toothpaste in the examined groups among patients brushing their teeth depending on the place of living.

\begin{tabular}{lcccc}
\hline \hline \multirow{2}{*}{ The type of toothpaste } & \multicolumn{2}{c}{ Nursing homes } & \multicolumn{2}{c}{ Family homes } \\
\cline { 2 - 5 } & $\begin{array}{c}\text { number of } \\
\text { people }\end{array}$ & $\%$ & $\begin{array}{c}\text { number of } \\
\text { people }\end{array}$ & $\%$ \\
\hline With fluoride & 29 & $93.54 \%$ & 66 & $80.49 \%$ \\
\hline Anti inflamation & 1 & $3.23 \%$ & 12 & $14.63 \%$ \\
\hline $\begin{array}{l}\text { Against } \\
\text { hypersensitivity }\end{array}$ & 1 & $3.23 \%$ & 3 & $3.66 \%$ \\
\hline Whitening & 0 & $0.00 \%$ & 1 & $1.22 \%$ \\
\hline Total & 31 & $100.00 \%$ & 82 & $100.00 \%$ \\
\hline
\end{tabular}

TABLE 3. Use of additional oral hygiene tools in the examined groups depending on the place of living.

\begin{tabular}{|c|c|c|c|}
\hline \multirow{3}{*}{ Group } & Yes & No & Total \\
\hline & \multicolumn{3}{|c|}{ number of people number of people number of people } \\
\hline & $\%$ & $\%$ & $\%$ \\
\hline \multirow{2}{*}{ Nursing homes } & 0 & 117 & 117 \\
\hline & $0.00 \%$ & $100.00 \%$ & $100.00 \%$ \\
\hline \multirow{2}{*}{ Family homes } & 39 & 84 & 123 \\
\hline & $31.71 \%$ & $68.29 \%$ & $100.00 \%$ \\
\hline \multirow{2}{*}{ Total } & 39 & 201 & 240 \\
\hline & $16.25 \%$ & $83.75 \%$ & $100.00 \%$ \\
\hline
\end{tabular}

(Nr KE-02554/224/2004). The obtained study results were submitted to statistic analysis and presented in tables $1-5$.

\section{RESULTS}

Questionnaire survey revealed that seniors residing in nursing homes and having their own teeth brushed them most frequently once a day, e.g. $37.25 \%$ of the examined, whereas the surveyed who lived with their families - twice a day $-47.67 \%$. In the group of Nursing Homes patients, $39.22 \%$ people did not brush their teeth at all. Quite small percentage of seniors who brushed their teeth after every meal was noted in both groups: only $3.92 \%$ among the surveyed from the Nursing Homes and $15.12 \%$ of those living with their families. Statistical analysis proved extremely essential differences in the frequency of tooth brushing between the groups $(\mathrm{p}<0.00001)$ (Table 1$)$.

In both investigated groups, the people brushing their teeth most frequently used fluoride toothpastes $(94.54 \%$ seniors of the nursing homes and $80.49 \%$ seniors in family homes) (Table 2).

Additional oral aids were used by $31.71 \%$ of the surveyed living with their families, whereas the ones living in Nursing Homes did not use them at all $(p<0.00001)$. Seniors reporting to Clinical Dental Centre of the Medical University of Lublin most frequently used tooth picks $-74.36 \%$ and mouth-washes $-56.41 \%$ and less frequently dental floss $-17.95 \%$ (Table 3 and 4 ).

Both, among the residents of Nursing Homes and those living in their family homes, the surveyed most frequently reported replacing their toothbrushes at least every 3 months $-77.42 \%$ and $67.07 \%$ respectively. Statistical analysis did not reveal any essential differences between the groups $(\mathrm{p}=0.56)($ Table 5).

TABLE 4. The type of additional oral hygiene tools in the group of people living in the family homes.

\begin{tabular}{lcc}
\hline \hline \multirow{2}{*}{$\begin{array}{c}\text { The type of additional } \\
\text { oral hygiene tools }\end{array}$} & \multicolumn{2}{c}{ Family homes } \\
\cline { 2 - 3 } & number of people & $\%$ \\
\hline Dental floss & 7 & $17.95 \%$ \\
\hline Tooth picks & 29 & $74.36 \%$ \\
\hline Mouth-washes & 22 & $56.41 \%$ \\
\hline
\end{tabular}

TABLE 5. The frequency of toothbrush replacement in the examined groups among patients brushing their teeth depending on the place of living.

\begin{tabular}{|c|c|c|c|c|}
\hline \multirow[b]{2}{*}{ Group } & $\begin{array}{c}\text { Every } \\
2 \text { months }\end{array}$ & $\begin{array}{c}\text { Every } \\
3 \text { months }\end{array}$ & Rarely & Total \\
\hline & $\begin{array}{c}\text { number of } \\
\text { people } \\
\%\end{array}$ & $\begin{array}{c}\text { number of } \\
\text { people } \\
\%\end{array}$ & $\begin{array}{c}\text { number of } \\
\text { people } \\
\%\end{array}$ & $\begin{array}{c}\text { number of } \\
\text { people } \\
\%\end{array}$ \\
\hline \multirow{2}{*}{$\begin{array}{l}\text { Nursing } \\
\text { homes }\end{array}$} & 2 & 5 & 24 & 31 \\
\hline & $6.45 \%$ & $16.13 \%$ & $77.42 \%$ & $100.00 \%$ \\
\hline \multirow{2}{*}{$\begin{array}{l}\text { Family } \\
\text { homes }\end{array}$} & 8 & 19 & 55 & 82 \\
\hline & $9.76 \%$ & $23.17 \%$ & $67.07 \%$ & $100.00 \%$ \\
\hline \multirow{2}{*}{ Total } & 10 & 24 & 79 & 113 \\
\hline & $8.85 \%$ & $21.24 \%$ & $69.91 \%$ & $100.00 \%$ \\
\hline \multicolumn{5}{|c|}{ Statistical analysis: $\mathrm{Chi}^{2}=1.15 ; \mathrm{p}=0.56$} \\
\hline
\end{tabular}




\section{DISSCUSION}

The analysis of hygiene habits among the residents of Nursing Homes in Szczecin and neighboring towns was conducted by Stawska. The author stated the existence of hygiene care problems in the investigated group. Majority of the surveyed brushed their teeth twice a day $-44.44 \%$ or once a day $-42.60 \%$. Three times less people $(12.96 \%)$ than in author's own research (39.22\%) reported not cleaning their teeth at all. However, none of the seniors brushed their teeth after every meal [10]. While comparing the above results with the author's own research, it should be stated that among people living in Nursing Homes in Lublin 56.86\% brushed their teeth once and twice a day, which proves serious hygiene neglect.

Koczorowski et al. obtained slightly better results of the hygiene care frequency among residents of Nursing Homes in Poznań and a few towns in Wielkopolska. They stated that $33 \%$ of people brushed their teeth twice a day, $23 \%$ once a day, $12 \%$ three times a day, whereas $32 \%$ of the surveyed did not brush their teeth at all [11]. On the other hand, only $15 \%$ of the Nursing Home residents in Turkey (Ankara) had toothbrushes. In this group teeth were most frequently brushed once a day $-31 \% ; 27.60 \%$ of people brushed their teeth twice daily and $13.80 \%$ - three times daily, while $27.60 \%$ of respondents reported brushing their teeth from time to time. Only 3 out of 193 people used dental floss or tooth picks [4]. This proves the lack of interest with additional oral care aids in people not living in their family homes, which is confirmed by the results of own research. Residents of Lublin Nursing Homes did not use additional oral care aids at all. Among the residents of nursing homes in Brazil (Taubate), $7.3 \%$ people used dental floss, $8 \%$ - tooth picks and $4 \%$ - mouth-washes. Among the surveyed, $26 \%$ did not brush their teeth and $21.3 \%$ brushed them 3 times a day, $18 \%$ - twice a day, $15.3 \%$ - once a day and $4.7 \%$ - four times a day. Brushing their tongue regularly was confirmed by $10.9 \%$ of seniors . Problems with managing oral hygiene were reported by $20 \%$ respondents, mainly because of impaired dexterity, dependence on caregivers and poor health [12]. On the other hand, in the group of Nursing Homes residents in Turkey (Istanbul), 81\% had never used dental floss and only $3 \%$ used mouthwashes every day or once a week and $31 \%$ people brushed their teeth less frequently than once a day [13].

A higher percentage of seniors not performing any hygiene procedures was noted among the residents of institutional care units in Germany (Berlin) - 59.4\% [14] as well as in England (Avon) - 45.8\% than in the author's own research. Among the residents from England, 29.7\% reported problems with teeth brushing. Nursing homes staff did not help with their daily hygiene procedures; however, sometimes such help was used by $2.5 \%$ of seniors [15].

Far better results were noted among the students of the University of the Third Age (UTA). Among people in the studied group, $88.50 \%$ brushed their teeth twice or three times a day, $8 \%$ once a day and $3 \%$ only rinsed their mouths. Among seniors living with their families in Lublin, $47.67 \%$ brushed their teeth twice a day, $32.56 \%$ once a day, $15.12 \%$ after every meal, and $4.65 \%$ did not brush teeth at all. These diversities may result from greater health awareness of the surveyed from Wrocław because of their education, e.g. $45 \%$ had higher education, $54 \%$ secondary and only $1 \%$ elementary education [16]. In the author's own research, $18.70 \%$ people living with their families had higher education and $30.89 \%$ elementary education. Twice as high percentage of seniors reporting to Clinical Dental Centre (CDC) of the Medical University in Lublin used tooth picks: CDC $74.36 \%$ and UTA $-35 \%$ and mouthwashes: CDC $-56.41 \%$ and UTA $-26 \%$. The percentage of the investigated using dental floss was similar in both groups of respondents and was $17.95 \%$ for Lublin residents and $22 \%$ for seniors from Wrocław. Quite a small percentage of UTA students used interdental brushes and oral irrigators [16].

Frączak et al. noted better results while examining 80 people from Szczecin. The authors stated that the majority of the surveyed brushed their teeth twice a day e.g. 60 seniors, 10 people brushed their teeth 3 times a day - men only, the subsequent 10 women only, more than 3 times a day. The majority of the investigated replaced their toothbrushes only when they showed the signs of wear -40 people; 20 of the surveyed replaced their toothbrushes once a month and the remaining 20 - once in every 2-3 months [9].

Among the investigated from Lithuania 37\% brushed their teeth once a day and $30 \%$ twice a day. In the studied group $57 \%$ of seniors reported always using fluoride toothpastes, the remaining people nearly always or sometimes and $19 \%$ cleaned their interdental spaces every day [17]. Whereas $65.4 \%$ of Indian patients reported brushing their teeth using toothbrushes with a toothpaste or tooth powder, $19.5 \%$ used other hygiene techniques and $14.1 \%$ had never brushed their teeth, they just rinsed their mouths with water $[18,19]$. Among the surveyed from Japan 28.85 used interdental brushes [20].

Based on own research considerable neglect and irregularities were stated in relation to hygiene habits among the residents of Lublin Nursing Homes. This applies to the frequency of tooth brushing - once a day or not at all, not using additional oral hygiene aids, rare replacement of a toothbrush. Those who did not brush their teeth possessed only residual dentition and thought that there was no need of brushing single teeth. The reason of this state may be probably specific character of social and living environment, limited access to the above mentioned products, smaller number of preserved natural teeth, worse physical and psychological state resulting from the lack of strength and willingness to proper oral hygiene, deterioration of dexterity, lesser needs concerning their dentition as well as lack of knowledge on the prophylaxis of oral diseases. There are no people able to carry out proper hygiene training adapted to the patients' age and draw seniors' attention to hygiene neglect. For the sake of the lack of training and small number of Nursing Homes staff as well as the lack of constant dental care, in this sphere elderly people may count on potential help of their relatives or they can rely just on themselves. Similar conclusions were drawn by other authors $[4,6,10-14]$. 


\section{CONCLUSIONS}

1. Residents of Nursing Homes most frequently revealed neglect and irregularities in the oral hygiene rather than seniors living with their families.

2. Population of the elderly, especially residents of Nursing Homes, should be provided with a complex dental care including proper oral hygiene instructions adjusted to patients' age and their dexterity as well as broadening their knowledge on the prophylaxis of the oral diseases.

\section{REFERENCES}

1. Borreani E, Jones K, Scambler S, Gallagher JE. Informing the debate on oral health care for older people: a qualitative study of older people's views on oral health and oral health care. Gerodontol. 2010;27:11-8.

2. Panzeri H, Lara EHG, Paranhos Hde FO, et al. In vitro and clinical evaluation of specific dentifrices for complete denture hygiene. Gerodontol. 2009;26:26-33.

3. Thompson GW, Kreisel PSJ. The impact of the demographics of aging and the edentulous condition on dental care services. J Prosthet Dent. 1998;79:56-9.

4. Ünlüer Ş, Gökalp S, Doğan BG. Oral health status of the elderly in a residential home in Turkey. Gerodontol. 2007;24:22-9.

5. Frączak B, Stawska B. Potrzeby protetyczne pensjonariuszy Domów Pomocy Społecznej. Protet Stomatol. 2006;56:305-11.

6. Nicol R, Sweeney MP, McHugh S, Bagg J. Effectiveness of health care worker training on the oral health of elderly residents of nursing homes. Community Dent Oral Epidemiol. 2005;33:115-24.

7. Pawlik AA. „Gero-periodontologia” w kapsułce. Asyst Hig Stomatol. 2007;4:6-10.

8. Cichy M. Higiena jamy ustnej u ludzi w podeszłym wieku. Porad Stomatol. 2008;11:287-9.

9. Frączak B, Biskup M, Ey-Chmielewska H, et al. Stan błony śluzowej $\mathrm{i}$ higieny u pacjentów użytkujących uzupełnienia protetyczne stałe i ruchome na podstawie badań klinicznych i ankietowych. Protet Stomatol. $1995 ; 45: 17-9$.

10. Stawska B. Stomatologia geriatryczna - potrzeby, problemy i oczekiwania stomatologiczne pensjonariuszy domów pomocy społecznej. Rocz PAM. 2006;52:89-97.

11. Koczorowski R, Gawriołek M, Siniawska J. Porównawcza ocena stomatologicznych potrzeb pensjonariuszy Domów Opieki Społecznej z Poznania i terenu Wielkopolski. Dent Forum. 2008;36:27-33.

12. Marchini L, Vieira PC, Bossan TP, et al. Self-reported oral hygiene habits among institutionalised elderly and their relationship to the condition of oral tissues in Taubaté, Brazil. Gerodontol. 2006;23:33-7.

13. Ozkan Y, Özcan M, Kulak Y, et al. General health, dental status and perceived dental treatment needs of an elderly population in Istanbul. Gerodontol. 2011;28:28-36.

14. Knabe C, Kram P. Dental care for institutionalized geriatric patients in Germany. J Oral Rehabil. 1997;24:909-12.

15. Frenkel H, Harvey I, Newcombe RG. Oral health care among nursing home residents in Avon. Gerodontol. 2000;17:33-8.

16. Pregiel B, Wrzyszcz-Kowalczyk A, Fita K, et al. Higiena jamy ustnej i nawyki dietetyczne u słuchaczy Uniwersytetu Trzeciego Wieku we Wrocławiu. Porad Stomatol. 2007;12:344-52.

17. Vyšniauskaité S, Kammona N, Vehkalahti MM. Number of teeth in relation to oral health behaviour in dentate elderly patients in Lithuania. Gerodontol. 2005;22:44-51.

18. Shah N, Parkash H, Sunderam KR. Edentulousness, denture wear and denture needs of Indian elderly - a community-based study. J Oral Rehabil. 2004;31:467-76.

19. Shah N, Sundaram KR. Impact of socio-demographic variables, oral hygiene practices, oral habits and diet on dental caries experience of Indian elderly: a community-based study. Gerodontol. 2004;21:43-50.

20. Aleksejuniene J, Holst D, Eriksen HM. Patterns of dental caries and treatment experience in elderly Lithuanians. Gerodontol. 2000;17:77-86.

\section{Corresponding author}

dr n. med. Katarzyna Kamińska-Pikiewicz

Karmelicka 7 st., 20-081 Lublin, Poland

tel. 81 528-79-20

E-mail: k.kam@op.pl 